\title{
Water mass evolution of the Greenland Sea since late glacial times
}

\author{
M. M. Telesiński ${ }^{1}$, R. F. Spielhagen ${ }^{1,2}$, and H. A. Bauch ${ }^{1,2}$ \\ ${ }^{1}$ GEOMAR Helmholtz Centre for Ocean Research Kiel, Wischhofstrasse 1-3, 24148 Kiel, Germany \\ ${ }^{2}$ Academy of Sciences, Humanities, and Literature, 53151 Mainz, Germany \\ Correspondence to: M. M. Telesiński (mtelesinski@geomar.de)
}

Received: 15 August 2013 - Published in Clim. Past Discuss.: 30 August 2013

Revised: 21 November 2013 - Accepted: 6 December 2013 - Published: 16 January 2014

\begin{abstract}
Four sediment cores from the central and northern Greenland Sea basin, a crucial area for the renewal of North Atlantic deep water, were analyzed for planktic foraminiferal fauna, planktic and benthic stable oxygen and carbon isotopes as well as ice-rafted debris to reconstruct the environmental variability in the last $23 \mathrm{kyr}$. During the Last Glacial Maximum, the Greenland Sea was dominated by cold and sea-ice bearing surface water masses. Meltwater discharges from the surrounding ice sheets affected the area during the deglaciation, influencing the water mass circulation. During the Younger Dryas interval the last major freshwater event occurred in the region. The onset of the Holocene interglacial was marked by an increase in the advection of Atlantic Water and a rise in sea surface temperatures (SST). Although the thermal maximum was not reached simultaneously across the basin, benthic isotope data indicate that the rate of overturning circulation reached a maximum in the central Greenland Sea around $7 \mathrm{ka}$. After $6-5 \mathrm{ka}$ a SST cooling and increasing sea-ice cover is noted. Conditions during this so-called "Neoglacial" cooling, however, changed after 3 ka, probably due to enhanced sea-ice expansion, which limited the deep convection. As a result, a well stratified upper water column amplified the warming of the subsurface waters in the central Greenland Sea, which were fed by increased inflow of Atlantic Water from the eastern Nordic Seas. Our data reveal that the Holocene oceanographic conditions in the Greenland Sea did not develop uniformly. These variations were a response to a complex interplay between the Atlantic and Polar water masses, the rate of sea-ice formation and melting and its effect on vertical convection intensity during times of Northern Hemisphere insolation changes.
\end{abstract}

\section{Introduction}

The Nordic Seas are an important region for the global oceanic system. First of all, they are the main gateway between the Arctic and North Atlantic oceans (Hansen and Østerhus, 2000). They also play a fundamental role in the overturning circulation being one of the deep water formation regions (Marshall and Schott, 1999). Paleoceanographic studies in this area are crucial to improve our understanding of the pace and amplitude of natural variability during the last glacial-interglacial transition and within the Holocene. While a significant number of detailed studies focuses on the eastern part of the region, along the North Atlantic Current (NAC) flow (e.g., Hald et al., 2007; Risebrobakken et al., 2011), less effort has been devoted to its central and western parts (e.g., Fronval and Janssen, 1997; Bauch et al., 2001). Problems with the accessibility due to the ice cover and low sedimentation rates (Nørgaard-Pedersen et al., 2003; Telesiński et al., 2013), which do not allow high resolution studies, are among the main reasons here.

Recently, Telesiński et al. (2013) presented a new record from the central Greenland Sea that allowed studying the oceanographic changes since the late glacial $(22.3 \mathrm{ka})$ in a relatively high temporal resolution. That study revealed significant variability of the oceanic environment on multicentennial to multimillennial timescales. Although the record was generally in agreement with earlier studies, it also revealed some unusual features such as, e.g., an extreme freshwater-related planktic low- $\delta^{18} \mathrm{O}$ spike during the deglaciation and microfossil evidence for a late Holocene warming. Here we now correlate and compare that record with three other sediment cores from the northern Greenland Sea and with other paleoceanographic archives from the Nordic Seas to reconstruct the paleoceanography on a larger 
regional scale. Furthermore, subsurface temperature reconstructions and a first high-resolution benthic stable isotope record from the Greenland Sea are presented and allow assessing the spatial range of variability found in the central Greenland Sea and the history of the overturning circulation in the area.

\section{Study area}

The Nordic Seas constitute the only deep-water connection between the North Atlantic and the Arctic oceans (Fig. 1). Relatively warm and saline $\left(T \sim 6-11^{\circ} \mathrm{C}, S>35\right)$ Atlantic Water (AW) flows north along the Norwegian, Barents Sea and Svalbard continental margins and enters the Arctic through the Fram Strait and Barents Sea. In the west, cold, low-saline $\left(<0{ }^{\circ} \mathrm{C},<34.4\right)$ Polar Water $(\mathrm{PW})$ flows south through the Fram Strait and along the Greenland continental margin to enter the North Atlantic through the Denmark Strait (Rudels et al., 1999). The strong gradient between these two main surface water masses makes the Nordic Seas sensitive to climatic changes. The central part of the Nordic Seas is the domain of Arctic Water (ArW), a result of PW and AW mixing. ArW is separated from PW by the Polar Front and from AW by the Arctic Front (Swift, 1986).

The vertical structure of the water column in the central Greenland Sea consists of three layers. At the surface, there is a thin layer of Arctic Surface Water originating from the East Greenland Current (EGC). Underneath, a layer of Atlantic Intermediate Water exists, which is supplied from the NAC. The weakly stratified Greenland Sea Deep Water, a product of deep convection, is found below (Marshall and Schott, 1999).

The Nordic Seas are one of the areas where deep water convection and the formation of North Atlantic Deep Water (NADW) take place today (e.g., Rudels and Quadfasel, 1991; Marshall and Schott, 1999). The western branches of the NAC and the eastern branches of the EGC create a cyclonic circulation in the Greenland Sea and lead to doming of the upper water layers. As the two water masses mix, they increase their density and sink to the bottom (Hansen and $\varnothing$ sterhus, 2000). Subsequently, the water leaves the Nordic Seas as the Denmark Strait and Iceland-Scotland Overflow Waters.

Sea ice plays an important preconditioning role in the Greenland Sea compared to other convectional areas. In early winter, the formation of sea ice leads to brine rejection. The surface layer increases its density and sinks to about $150 \mathrm{~m}$ by mid-January. The sea-ice cover forms a wedge (Is Odden) extending far to the northeast, also over the Vesterisbanken area. Preconditioning continues later in the winter, with mixed-layer deepening in the ice-free area (Nord Bukta) to $300-400 \mathrm{~m}$, induced by strong winds blown over the ice. Typically in March, near-surface densities are high enough to develop deep convection (down to $>2000 \mathrm{~m}$ ) in

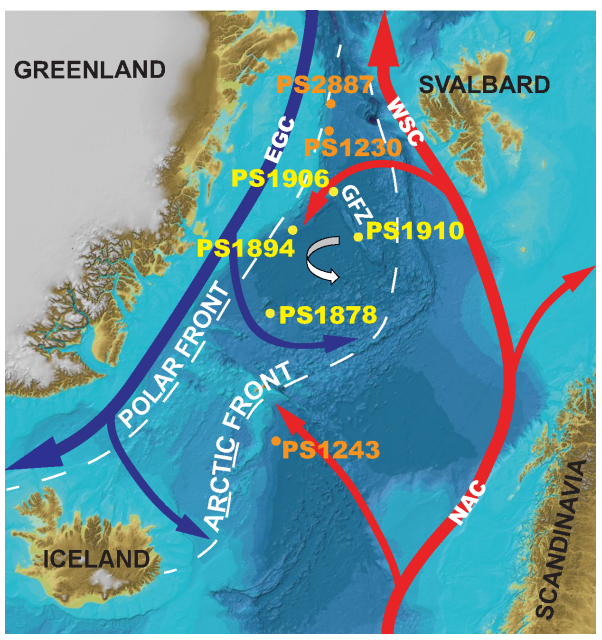

Fig. 1. Present day surface water circulation in the Nordic Seas. Cores used in this study are marked by yellow dots; other cores mentioned in text are marked by orange dots. Red arrows indicate Atlantic Water, blue arrows - Polar Water, white broken lines - oceanographic fronts. White arrow - present-day deep convection (Marshall and Schott, 1999). EGC - East Greenland Current, NAC - North Atlantic Current, WSC - West Spitsbergen Current, GFZ - Greenland Fracture Zone. Bathymetry from The International Bathymetric Chart of the Arctic Ocean (http://www.ibcao. org, 2012).

the Greenland Sea, if the meteorological conditions are favorable (Marshall and Schott, 1999).

At present, the sites investigated in this study are all located within the ArW domain. A detailed description of site PS1878 was given by Telesiński et al. (2013). The three sites from the northern Greenland Sea, PS1894, PS1906 and PS1910, are located on the Greenland continental slope, on the northern and on the southern part of the Greenland Fracture Zone crest, respectively.

\section{Material and methods}

The sediment cores used in this study were retrieved during the ARK-VII/1 expedition of RV Polarstern in 1990 (Fig. 1). Core PS1878 is compiled from a giant box core PS1878-2 and a kasten core PS1878-3 (Telesiński et al., 2013), whereas the three others are giant box cores (Table 1). All cores consisted of brown to olive grey sediments of clay to silty sand. They were sampled continuously every $1 \mathrm{~cm}$. Additionally, surface sediments of cores PS1894, PS1906 and PS1910 were collected. Further preparation included freeze-drying, wet-sieving with deionized water through a $63 \mu \mathrm{m}$ mesh, and dry-sieving into size fractions using 100, 125, 250, 500 and $1000 \mu \mathrm{m}$ sieves. Each size fraction was weighed.

In representative splits ( $>300$ specimens) of the 100 $250 \mu \mathrm{m}$ size fraction planktic foraminifera were counted. Samples containing less than 100 specimens were not used 
Table 1. Cores used in the study.

\begin{tabular}{lccccc}
\hline Core & Latitude & Longitude & $\begin{array}{c}\text { Water } \\
\text { depth } \\
(\mathrm{m})\end{array}$ & $\begin{array}{c}\text { Core } \\
\text { type }\end{array}$ & $\begin{array}{c}\text { Core } \\
\text { length } \\
(\mathrm{cm})\end{array}$ \\
\hline PS1878-2 & $73^{\circ} 15.1^{\prime} \mathrm{N}$ & $9^{\circ} 00.9^{\prime} \mathrm{W}$ & 3038 & $\mathrm{BC}^{\mathrm{a}}$ & 27 \\
$\mathrm{PS} 1878-3$ & $73^{\circ} 15.3^{\prime} \mathrm{N}$ & $9^{\circ} 00.7^{\prime} \mathrm{W}$ & 3048 & $\mathrm{KC}^{\mathrm{b}}$ & 113 \\
PS1894-7 & $75^{\circ} 48.8^{\prime} \mathrm{N}$ & $8^{\circ} 15.5^{\prime} \mathrm{W}$ & 1992 & $\mathrm{BC}^{\mathrm{a}}$ & 42 \\
PS1906-1 & $76^{\circ} 50.5^{\prime} \mathrm{N}$ & $2^{\circ} 09.0^{\prime} \mathrm{W}$ & 2990 & $\mathrm{BC}^{\mathrm{a}}$ & 33 \\
PS1910-1 & $75^{\circ} 37.0^{\prime} \mathrm{N}$ & $1^{\circ} 19.0^{\prime} \mathrm{E}$ & 2448 & $\mathrm{BC}^{\mathrm{a}}$ & 33 \\
\hline
\end{tabular}

${ }^{\mathrm{a}} \mathrm{BC}-$ giant box core, ${ }^{\mathrm{b}} \mathrm{KC}-$ kasten core.

for the relative species abundance analysis. The number of planktic foraminifera per $1 \mathrm{~g}$ dry sediment was calculated to serve as a semiquantitative proxy for bioproductivity.

Identification and counting of several mineral grain types $>250 \mu \mathrm{m}$ was used as a proxy for the intensity of ice-rafting and the identification of tephra layers. As ice-rafted debris (IRD) we interpret all lithic grains $>250 \mu \mathrm{m}$, except for unweathered volcanic glass. In the high latitudes, such coarse particles can be transported into a deep ocean basin preferentially by icebergs while sea ice mainly transports finer material (Clark and Hanson, 1983; Nürnberg et al., 1994).

For the analysis of stable oxygen and carbon isotopes, specimens of the planktic foraminiferal species Neogloboquadrina pachyderma (sin.) (all cores) and two benthic species - the epibenthic Cibicidoides wuellerstorfi and the shallow infaunal Oridorsalis umbonatus (cores PS1894, PS1910 and PS1878) - were used. Because of departures from isotopic calcite equilibrium, the measured $\delta^{18} \mathrm{O}$ values of these two species were corrected by +0.64 and $+0.36 \%$, respectively (cf. Duplessy et al., 1988). Twenty-five specimens were picked from the 125-250 $\mu \mathrm{m}$ (N. pachyderma (sin.) and O. umbonatus) and $250-500 \mu \mathrm{m}(C$. wuellerstorfi) size fractions. All stable isotope analyses were carried out in the isotope laboratories of GEOMAR Helmholtz Centre for Ocean Research Kiel and the University of Kiel on Finnigan MAT 251 and Thermo MAT 253 mass spectrometers. Results are expressed in the $\delta$ notation referring to the PDB (Pee Dee Belemnite) standard and are given as $\delta^{18} \mathrm{O}$ and $\delta^{13} \mathrm{C}$ with an analytical accuracy of $<0.06$ and $<0.03 \%$, respectively.

Absolute summer subsurface temperatures $(100 \mathrm{~m}$ water depth) were calculated at site PS1878 between 15 and $0 \mathrm{ka}$ using transfer functions based on a modern training set from the Arctic (Husum and Hald, 2012) and the C2 software, version 1.7.2 (Juggins, 2011). A weighted average partial least-squares statistical model with three components (WAPLS C3) and leave-one-out ("jack knifing") cross validation was used. The root mean-squared error of prediction is $0.52^{\circ} \mathrm{C}$. Unlike Husum and Hald (2012), who used the $>100 \mu \mathrm{m}$ size fraction, we ran the transfer function using the $100-250 \mu \mathrm{m}$ size fraction. Although the coarser sediments contained relatively few foraminifera, we acknowledge that this might have slightly biased the results. Further,
Table 2. AMS ${ }^{14} \mathrm{C}$ measurements and their calibrated ages for the cores used in the study (BP - before present).

\begin{tabular}{|c|c|c|c|}
\hline Lab. no. & $\begin{array}{r}\text { Depth } \\
(\mathrm{cm})\end{array}$ & $\begin{array}{r}{ }^{14} \mathrm{C} \text { age } \pm \\
\text { standard } \\
\text { deviation }\end{array}$ & $\begin{array}{r}\text { Calibrated } \\
\text { age } \\
(\mathrm{yr} \mathrm{BP})\end{array}$ \\
\hline \multicolumn{4}{|c|}{ Core PS1878-2 } \\
\hline Poz-45376 & 0.5 & $775 \pm 35$ & 426 \\
\hline Poz-45377 & 12.5 & $3300 \pm 40$ & 3143 \\
\hline \multicolumn{4}{|c|}{ Core PS1878-3 } \\
\hline Poz-45378 & 11.5 & $3295 \pm 35$ & 3139 \\
\hline Poz-45380 & 19.5 & $4525 \pm 35$ & 4746 \\
\hline Poz-54381 & 25.5 & $5580 \pm 50$ & 5961 \\
\hline Poz-54382 & 30.5 & $6760 \pm 50$ & 7295 \\
\hline Poz-45384 & 39.5 & $8410 \pm 60$ & 9028 \\
\hline Poz-45385 & 58.5 & $11100 \pm 60$ & 12613 \\
\hline KIA 47284 & 95.5 & $16620 \pm 110$ & 19266 \\
\hline \multicolumn{4}{|c|}{ Core PS1894-7 } \\
\hline KIA 7088 & 0.5 & $3845 \pm 40$ & 3794 \\
\hline KIA 47258 & 5.5 & $5390 \pm 35$ & 5773 \\
\hline KIA 7089 & 9.5 & $5745 \pm 40$ & 6174 \\
\hline KIA 47259 & 16.5 & $8075 \pm 45$ & 8528 \\
\hline KIA 7090 & 21.5 & $8910 \pm 55$ & 9564 \\
\hline KIA 7091 & 35.5 & $14430 \pm 70$ & 17051 \\
\hline \multicolumn{4}{|c|}{ Core PS1906-1 } \\
\hline KIA 7084 & 4.5 & $4360 \pm 30$ & 4482 \\
\hline KIA 7083 & 11.5 & $7965 \pm 40$ & 8420 \\
\hline KIA 7082 & 22.5 & $17040 \pm 80$ & 19731 \\
\hline KIA 7081 & 32.5 & $19130 \pm 90$ & 22334 \\
\hline \multicolumn{4}{|c|}{ Core PS1910-1 } \\
\hline KIA 44390 & 0.5 & $2655 \pm 30$ & 2336 \\
\hline Poz-45386 & 4.5 & $4820 \pm 35$ & 5122 \\
\hline Poz-45387 & 11.5 & $6950 \pm 50$ & 7457 \\
\hline KIA 44393 & 17.5 & $11340 \pm 50$ & 12794 \\
\hline Poz-45388 & 30.5 & $1680 \pm 100$ & 19625 \\
\hline
\end{tabular}

reconstructed temperatures below $2{ }^{\circ} \mathrm{C}$ are considered to be uncertain as the modern training set does contain very few data points below $2{ }^{\circ} \mathrm{C}$ (Husum and Hald, 2012).

\section{Chronology}

AMS ${ }^{14} \mathrm{C}$ datings were performed on monospecific samples of $N$. pachyderma (sin.) (Table 2). All radiocarbon ages were corrected for a reservoir age of $400 \mathrm{yr}$, calibrated using Calib Rev 6.1.0 software (Stuiver and Reimer, 1993) and the Marine09 calibration curve (Reimer et al., 2009) and are given in thousand calendar years before $1950 \mathrm{AD}(\mathrm{ka})$.

The records cover the last ca. 20-23 kyr. The three box cores from the northern Greenland Sea have average 


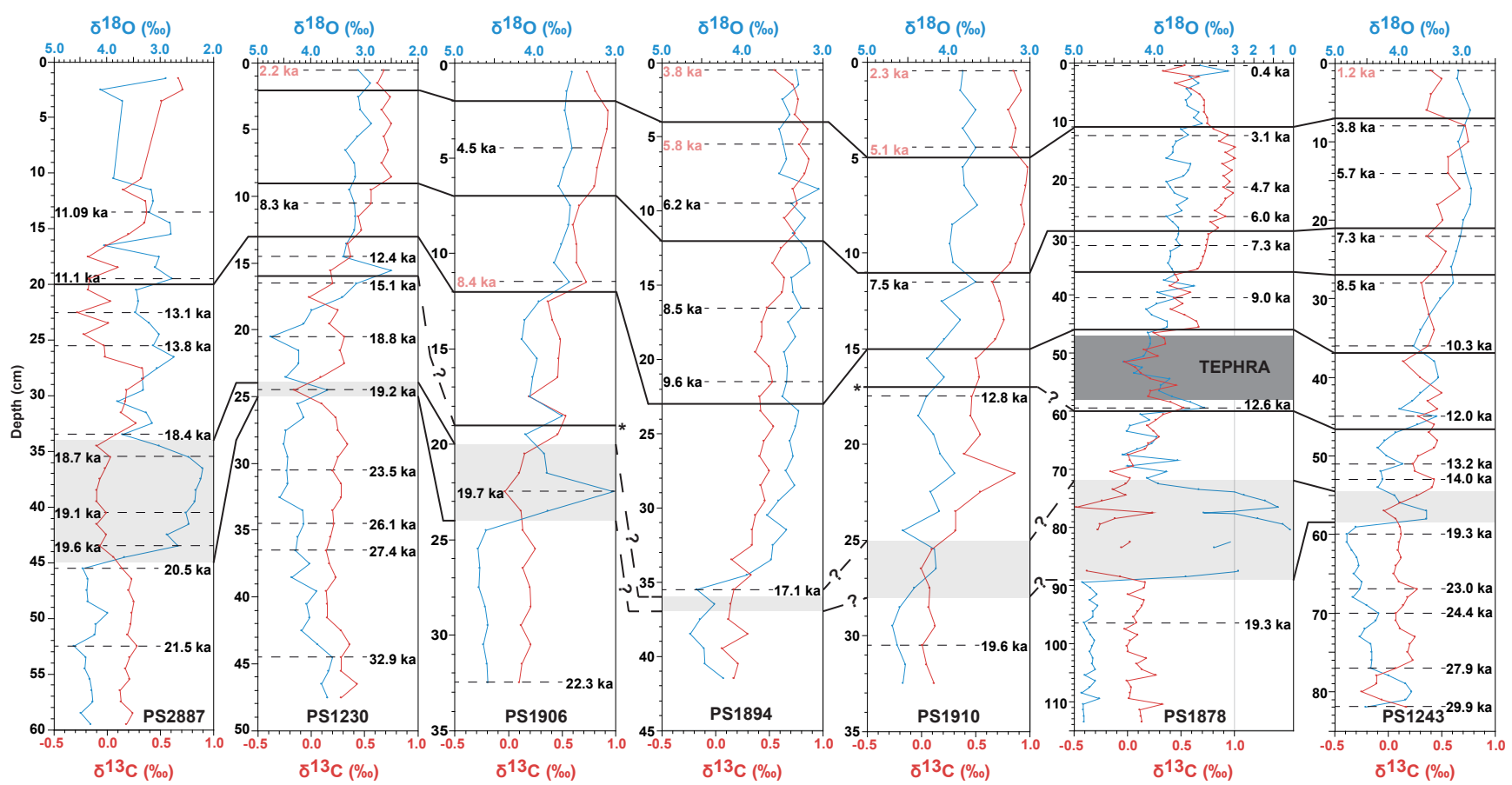

Fig. 2. Planktic oxygen and carbon stable isotope records of cores from the Nordic Seas and suggested correlation. Calibrated AMS ${ }^{14} \mathrm{C}$ dates are shown. Dates excluded from the correlation are marked in pale red. Light grey shadings indicate the light carbon and oxygen isotope excursions interpreted as freshwater discharges, marking the onset of the deglaciation.

sedimentation rates of $1.5-2.0 \mathrm{~cm} \mathrm{kyr}^{-1}$. These low rates, together with bioturbation and uncertain reservoir ages, make age models of these records unreliable if based only on ${ }^{14} \mathrm{C}$ datings. This is best illustrated by relatively old ages yielded from the surface samples of these cores (2.3-3.8 ka). However, the surface sample of core PS1878 yielded a younger age $(0.426 \mathrm{ka})$ and contained recent sediments (Telesiński et al., 2013). Therefore we assume that sedimentation in the entire study area did not terminate in the late Holocene. To account for the apparent inaccuracy of part of the AMS ${ }^{14} \mathrm{C}$ dates we attempted to improve the consistency of the age models of these cores by correlating the stable isotope data (and, in a few cases, also other proxies) and using linear interpolation between correlated points and reliable ${ }^{14} \mathrm{C}$-dated samples. In addition to our own data, we also used three nearby records of comparable sedimentation rates, time range and water depths. These include cores PS2887 (Nørgaard-Pedersen et al., 2003) as well as PS1230 from the western Fram Strait and PS1243 from the SW Norwegian Sea (Bauch et al., 2001). As the base for the correlation we used core PS1878, which has the highest temporal resolution and a reliable chronological framework based on ${ }^{14} \mathrm{C}$ datings in the younger part of the record (Fig. 2). Due to poorer ${ }^{14} \mathrm{C}$ age control and more speculative reservoir ages in the older part of the records, our improved age model is restricted to the last $15 \mathrm{kyr}$.

\section{Results}

\subsection{Planktic foraminifera, ice-rafted detritus (IRD) and reconstructed subsurface temperatures}

Four of our faunal records from the Greenland Sea show significantly different planktic foraminiferal abundances (Fig. 3), most likely due to different sedimentation rates. Therefore, absolute numbers of foraminiferal specimens in individual samples are not a meaningful proxy when cores are compared with one another. The records begin with relatively low abundances of the foraminiferal fauna strongly dominated by $N$. pachyderma $(\sin$.) (Fig. 4, between ca. 23 and $12 \mathrm{ka}$ ), a polar species dwelling at water depths of ca. 50-200 m (Carstens et al., 1997). There are, however, a number of prominent, short-lived peaks of high foraminiferal abundance. They are most common and most prominent in core PS1878, supposedly due to its highest time resolution, but they are also noticeable in cores PS1906 and PS1894.

A significant early change among the faunal data is observed in core PS1894. Here, an increase to $20-30 \%$ is found for the subpolar species $N$. pachyderma (dex.) and Turborotalita quinqueloba already around $17 \mathrm{ka}$. In the other cores a similar change is not noted until ca. $12 \mathrm{ka}$ when both the percentages of subpolar species and the total abundance increase. Throughout the remaining part of the records the abundance stays high although significant variability can be observed. The portions of subpolar species remain high for 


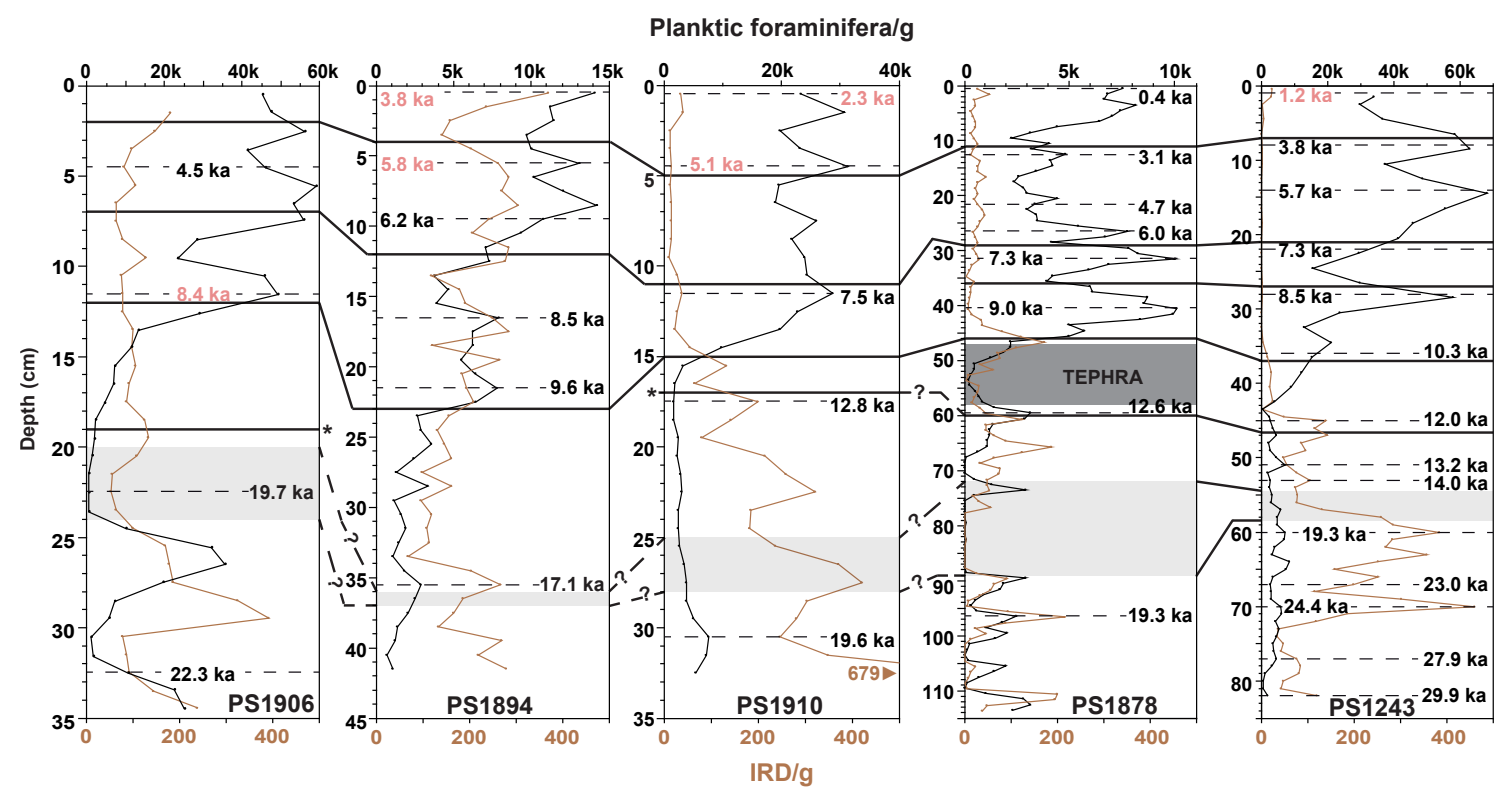

Fig. 3. Planktic foraminifera and IRD abundance (per $1 \mathrm{~g}$ dry sediment) of cores used in this study and core PS1243. Correlation and ages as in Fig. 2.

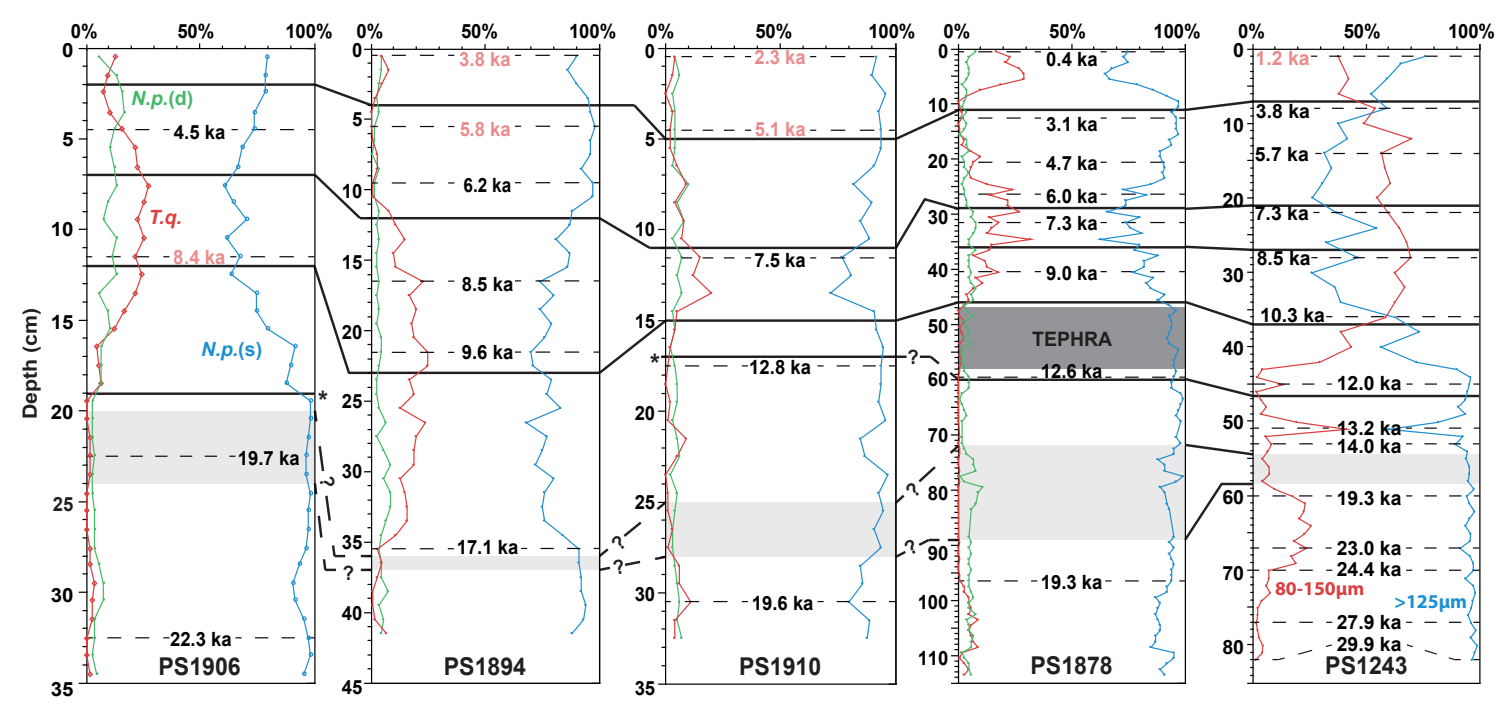

Fig. 4. Relative abundances of the three most common planktic foraminifera species in cores used in this study and core PS1243. N.p. (s) - N. pachyderma (sin.), N.p. (d) - N. pachyderma (dex.), T.q. - T. quinqueloba. Correlation and ages as in Fig. 2. Note the different size fractions used in core PS1243.

a few thousand years and then decrease gradually and unsimultaneously to reach pre-Holocene values $(<10-20 \%)$ again after ca. $5 \mathrm{ka}$. A second, major increase can be observed after $3 \mathrm{ka}$ in core PS1878 and, less clearly, PS1894. We did not find any significant signs of dissolution in the studied foraminifera. Both tests of robust $N$. pachyderma and more fragile subpolar species are generally well preserved throughout the cores.

As expected, the IRD records show high amounts of coarse lithogenic grains in the glacial part and low numbers during the Holocene (Fig. 3). Only the IRD content of core PS1894 remains relatively high throughout the entire record with slightly lower values between ca. 17 and $10 \mathrm{ka}$. In core PS1894, as well as in the lower part of cores PS1906 and PS1878, the IRD content seems to be positively correlated with the foraminiferal abundance, while in core PS1910 and in the upper part of PS1906 and PS1878 these two proxies appear inversely correlated.

The subsurface temperature record of core PS1878 shows values steadily increasing from around $2{ }^{\circ} \mathrm{C}$ around $15 \mathrm{ka}$ 
to a maximum of $3-3.5^{\circ} \mathrm{C}$ between 8 and $5.7 \mathrm{ka}$ (Fig. 7). Thereafter it decreases stepwise to values around $2{ }^{\circ} \mathrm{C}$ between 3.8 and $2.3 \mathrm{ka}$. Subsequently the record shows rapidly increasing temperatures with a peak value of ca. $3.5^{\circ} \mathrm{C}$ at $1.3 \mathrm{ka}$ and a decrease to $\mathrm{ca} .3^{\circ} \mathrm{C}$ until today.

\subsection{Stable isotopes}

The planktic oxygen isotope records start with relatively heavy and stable values of 4.3-4.9\%o (Fig. 2). After ca. $18 \mathrm{ka}$, sharp peaks of very light values (min. $0.15 \%$ ) occur (most pronounced in cores PS1906 and PS1878). Similar peaks are also found in cores PS1230, PS1243 (Bauch et al., 2001) and PS2887 (Nørgaard-Pedersen et al., 2003) that we used for the correlation. A trend towards lower $\delta^{18} \mathrm{O}$ values commences thereafter and lasts until the end of the record. A distinct, though irregular, variability can be observed within the trend (Figs. 2, 5).

The oldest part of all planktic carbon isotope records (>18 ka) exhibits low and stable values around $0.0-0.3 \%$. Simultaneous with the light $\delta^{18} \mathrm{O}$ peaks, the $\delta^{13} \mathrm{C}$ values decrease slightly and a trend of increasing values commences thereafter. Around $7 \mathrm{ka}$ the $\delta^{13} \mathrm{C}$ values reach a high plateau of $0.7-1.0 \%$, which lasts until $3 \mathrm{ka}$ and ends with a relatively sudden drop.

Because $O$. umbonatus and $C$. wuellerstorfi were partly absent in the lowermost parts of our cores, the benthic stable isotope records cover only the last $16 \mathrm{kyr}$ (Fig. 6). The oxygen isotope ratios of both benthic species generally show a decreasing trend parallel to the planktic record with values ca. $0.7-1.0 \%$ heavier than those of $N$. pachyderma (sin.). The epibenthic (C. wuellerstorfi) $\delta^{13} \mathrm{C}$ data follows the planktic $\delta^{13} \mathrm{C}$ records in terms of the main trends, but values are $0.2-1.0 \%$ higher and changes are of lower amplitude. The only major exception is the youngest $(<3 \mathrm{ka})$ part of record PS1894 in which benthic $\delta^{13} \mathrm{C}$ values continue to rise slightly while the planktic record decreases. All data sets are available from http://www.pangaea.de.

\section{Discussion}

\subsection{Last Glacial Maximum (LGM)}

The heavy $\delta^{18} \mathrm{O}$ values of $>4.5 \%$ in the Greenland Sea planktic records (Fig. 2) are typical for the late LGM waters in the Nordic Seas and Fram Strait (e.g., Sarnthein et al., 1995; Nørgaard-Pedersen et al., 2003). The low foraminiferal abundance and species diversity (Figs. 3, 4) are evidence of a low biological productivity in the Greenland Sea during the LGM. The latter might be a result of a perennial sea-ice cover that would strongly limit the penetration of sunlight and reduce the growth of phytoplankton that the foraminifera feed on.

Low $\delta^{13} \mathrm{C}$ values might suggest that the foraminifera lived in poorly ventilated water (cf. Duplessy et al., 1988), which

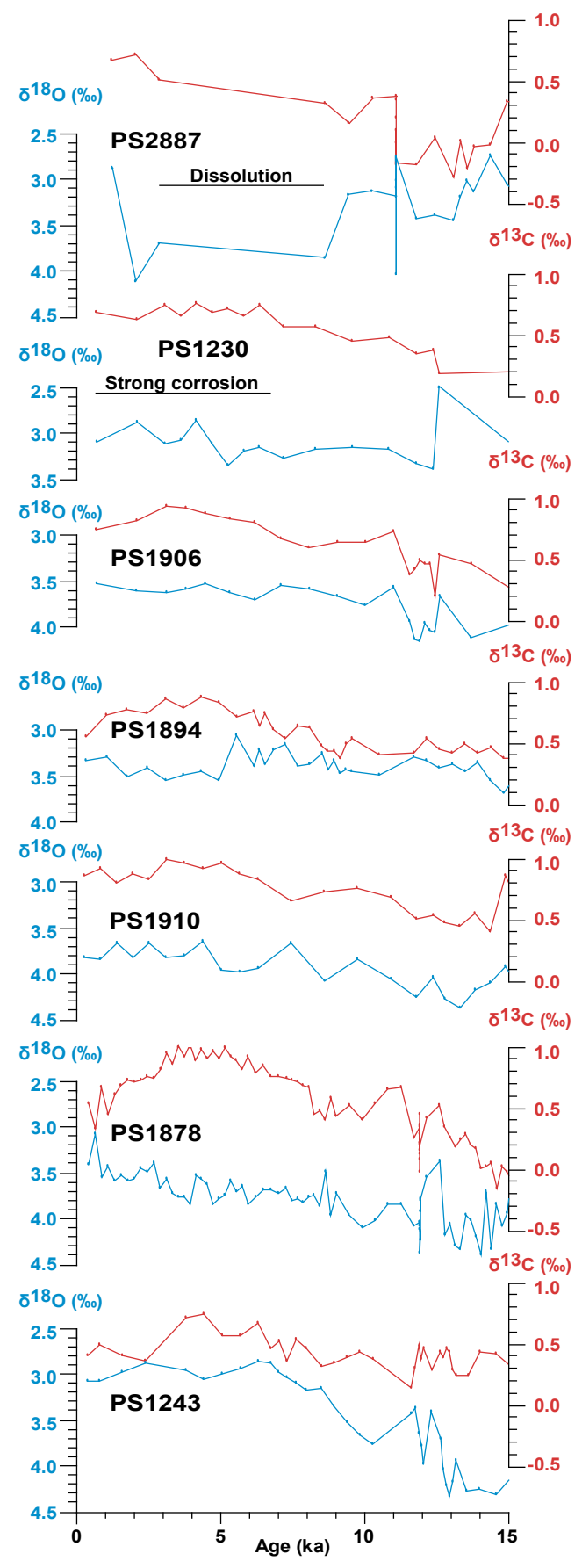

Fig. 5. Planktic oxygen and carbon stable isotope records of cores from the Nordic Seas plotted vs. age (since $15 \mathrm{ka}$ ).

seems obvious in a perennially ice-covered ocean. However, relatively high $\delta^{13} \mathrm{C}$ values $(>0.7 \%$ ) are found at present also in the perennially ice-covered areas of the central Arctic Ocean (Spielhagen and Erlenkeuser, 1994). Therefore, we hesitate to relate the low $\delta^{13} \mathrm{C}$ solely to the sea ice and/or strong stratification of the upper water layers. In addition, the carbon cycle in the glacial ocean may have been much 


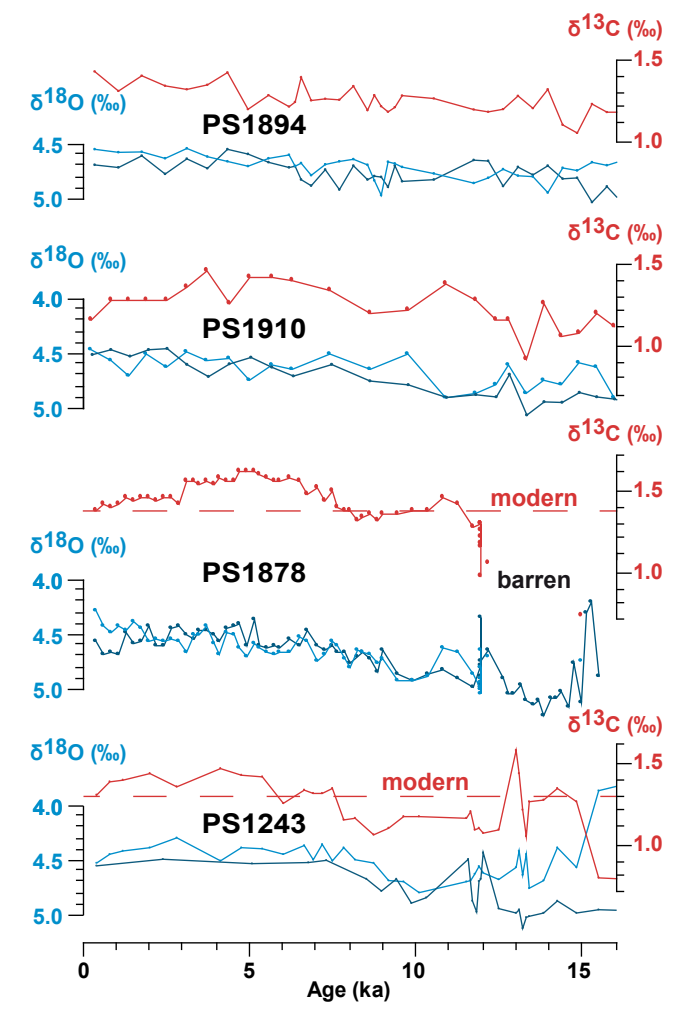

Fig. 6. Benthic oxygen (light and dark blue for $C$. wuellerstorfi and $O$. umbonatus, respectively) and carbon (red, C. wuellerstorfi) stable isotope records (in \%o vs. PDB) of cores PS1894, PS1910, PS1878 and PS1243 vs. age (since $16 \mathrm{ka}$ ). Broken lines in PS1878 and PS1243 mark modern (core-top) $\delta^{13} \mathrm{C}$ values of $C$. wuellerstorfi from the central Greenland Sea and site PS1243, respectively (Bauch and Erlenkeuser, 2003).

different than at present, which makes it difficult to unambiguously interpret the carbon isotope record in this interval.

The LGM sediments, especially in cores PS1906 and PS1910, contain high amounts of coarse ice-rafted debris if compared to younger layers (Fig. 3). This indicates that numerous icebergs were passing the area and dropping parts of their freight. The IRD concentration is highly variable and marked by numerous prominent peaks. These peaks clearly coincide with foraminiferal abundance peaks in cores PS1894, PS1878 and partly in core PS1906. As already discussed previously at site PS1878, the IRD peaks may represent sporadic and relatively short intervals of somewhat ameliorated conditions during times of decreased seasonal sea ice and slightly warmer surface water that resulted in a higher biological productivity, an increased IRD delivery, and thus, a higher sedimentation rate (Telesiński et al., 2013). The duration of these intervals may be overrepresented in the sediment record, the most compelling example being the IRD and foraminiferal peaks in core PS1906 at ca. 25-30 cm (ca. 20$22 \mathrm{ka}$ ). Variable sedimentation rates and the uncertainties in our age models for the LGM make it difficult to say whether the ameliorated conditions occurred basin wide or had a diachronous nature.

\subsection{Deglaciation}

Prominent low $\delta^{18} \mathrm{O}$ peaks accompanied by low $\delta^{13} \mathrm{C}$ values are recorded in the deglacial parts of cores PS1878 (ca. $18 \mathrm{ka}$ ) and PS1906 (19.7 ka), as well as PS1230 (19.2 ka, Bauch et al., 2001) and PS2887 (19.6-18.7 ka, Nørgaard-Pedersen et al., 2003). Similar, though more obscure features can be traced in cores PS1894 and PS1910 (Fig. 2). We interpret them as a result of the occurrence of isotopically light freshwater that lowered the regional surface and near-surface water salinity (Sarnthein et al., 1995; Spielhagen et al., 2004; Telesiński et al., 2013). In cores PS1906 and PS1878 the high amplitude of the $\delta^{18} \mathrm{O}$ peaks is accompanied by low IRD abundance in the respective intervals, which may suggest that the freshwater originated from catastrophic discharges from remote and/or terrestrial sources (e.g., outbursts from icedammed or subglacial lakes) rather than from a delivery by melting icebergs or nearby glaciers.

On the other hand, in the well-dated record from core PS2887 (Nørgaard-Pedersen et al., 2003) $\delta^{18} \mathrm{O}$ values remained low for more than $2 \mathrm{kyr}$ and the interpolated age of the spike in PS1878 (18-15 ka) fits well with the duration of the Heinrich stadial 1 (HS1). This may suggest that the freshwater persisted in the Greenland Sea for several thousand years and that the low foraminiferal abundance during this time might be a result of a salinity decrease below the level tolerated by planktic foraminifers. The lack of IRD might then be caused by a decrease in iceberg mobility and melt rate due to a rigid sea-ice cover that is expected to grow on top of a cold and freshened water surface.

We realize that the reservoir ages during the deglaciation, especially in the event when massive freshwater discharges rapidly affected the ocean's surface, remain highly uncertain and may have been considerably larger than at present (Waelbroeck et al., 2001; Hanslik et al., 2010; Stern and Lisiecki, 2013). Although the low sedimentation rates in some of our cores increase the uncertainty of the ${ }^{14} \mathrm{C}$-based age models, our regional comparison shows that the major deglacial freshwater discharges into the western Nordic Seas were roughly coeval. We consider that these events were likely triggered by the global sea level rise that started around $20 \mathrm{ka}$ (Clark and Mix, 2002) and came from the Greenland Ice Sheet and, perhaps, other circum-Arctic ice sheets (e.g., Sarnthein et al., 1995).

The low carbon isotope ratios during these freshwater events (Fig. 2) might be an indication of a reduced ventilation of the upper water column that was forced by a stable, highly stratified surface water lid (cf. Sarnthein et al., 1995; Spielhagen et al., 2004). If the surface stratification of the Greenland Sea was indeed a basin-wide phenomenon, as shown by our records, it supports the interpretation of a slowdown of the Atlantic Meridional Overturning Circulation 
(AMOC) during HS1 (McManus et al., 2004; Stanford et al., 2011; Telesiński et al., 2013). Furthermore, it also gives a rough chronological framework for the onset of the deglaciation (ca. $18 \mathrm{ka})$.

Although our benthic oxygen isotope records do not cover the initial part of HS1, the $\delta^{18} \mathrm{O}$ data of $O$. umbonatus indicate, like the planktic record, a distinct decrease around 15.5$15.0 \mathrm{ka}$ in PS1878 (Fig. 6). Such simultaneously occurring surface and bottom water depletions in $\delta^{18} \mathrm{O}$ are often interpreted as a result of brines rejected during sea-ice formation (e.g., Dokken and Jansen, 1999; Hillaire-Marcel and de Vernal, 2008). The likelihood that such brines formed in this way and could sink into intermediate or even much greater depths without significant dilution remains unproven (for a discussion see also Bauch and Bauch, 2001; Rasmussen and Thomsen, 2009). More recently, another scenario was proposed to explain the occurrence of light $\delta^{18} \mathrm{O}$ excursions during HS1 (Stanford et al., 2011). It suggests that meltwater loaded with fine sediments entered the Nordic Seas below the sea surface as a hyperpycnal flow. In our record, the negative benthic $\delta^{18} \mathrm{O}$ excursion at $15.5-15.0 \mathrm{ka}$ may result from such a mechanism. However, in the record studied by Stanford et al. (2011), the benthic oxygen isotope depletion has an amplitude larger than the planktic record, which is not observed in our record. Stanford et al. (2011) explain that, after losing the sediment load, the remaining relatively fresh, low density and low- $\delta^{18} \mathrm{O}$ water rose towards the surface (while strongly mixing with ambient water), resulting in the amplitude difference. Possibly the freshwater event in or close to the Greenland Sea released both a sediment-loaded and a largely sediment-free freshwater plume, which in combination may explain the strong near-surface and weaker bottom water $\delta^{18} \mathrm{O}$ decreases. The sediment-loaded plume mechanism may also explain the significant thickness of the layers in cores PS1878 and PS2887 with light $\delta^{18} \mathrm{O}$ values. While the plume was losing its load, sedimentation rates likely increased dramatically in the affected areas, resulting in relatively thick fine-grained deposits. The duration of the freshwater outbursts was probably significantly shorter than what appears from the linear age interpolation between the dating points. However, sea ice may have played a role as a further freshwater supplier by extending the range and duration of the freshwater event.

Following the freshwater event(s), planktic $\delta^{18} \mathrm{O}$ values increased to $\sim 4 \%$ or more (Figs. 2,5 ), indicating that the freshwater influence had decreased by this time. Also, the increasing $\delta^{13} \mathrm{C}$ values may further suggest that either the ventilation and/or the subsurface water structure with respect to stratification and bioproductivity had changed again.

The gradual and low-amplitude changes in the oxygen isotope record of PS1910 make it likely that the site was not directly influenced by major freshwater discharges. Shortlived freshwater events like those recorded in PS1878 between 15 and 13 ka may have taken place at site PS1910 (as well as PS1906 after the major event) but may be obscured by the core's low resolution. The generally heavy $\delta^{18} \mathrm{O}$ values throughout the deglaciation, as well as later on, do indicate a notable inflow of Atlantic waters to this area.

Site PS1894 is located on the Greenland continental slope, in direct proximity to the EGC and under the sea-ice cover. Thus, the lowest $\delta^{18} \mathrm{O}$ values in this record might result from the weakest influence of AW and the lowest salinity, compared to other sites. Today, the salinity at site PS1894 is 1-2 psu (practical salinity units) lower than farther to the east, in the ice-free areas (Thiede and Hempel, 1991). In contrast to the other sites, the main onset of the deglaciation (after $17 \mathrm{ka}$ ) seems to be characterized by a warming of the (sub)surface water rather than by a freshwater inflow, as the oxygen isotope ratio decrease is accompanied by the appearance of subpolar foraminiferal species (Figs. 2, 4). It is possible that a minor enhancement of the Atlantic Water inflow into the northwestern Greenland Sea coincided with and probably also contributed to the termination of LGM-type conditions and to the onset of deglacial changes at this site. It might seem counterintuitive that at this site, which is the one most affected by PW today, the subpolar species appeared so early and in such high amounts (around $20 \%$ ), especially since even in late Holocene sediments this group constitute less than $20 \%$ of the planktic fauna in this area (Husum and Hald, 2012). However, an occurrence of subpolar species, in particular those of smaller sizes, might indicate the advection of Atlantic waters subducted below stratified and sea-ice covered surface water layers (Bauch et al., 2001). Such a mechanism is confirmed by modern oceanographic measurements on a W-E profile across the Greenland Sea, showing higher subsurface temperatures at stations covered with sea ice than in ice-free areas (Thiede and Hempel, 1991).

Although the PS1894 oxygen isotope record does not indicate any major direct freshwater discharges in this area (Fig. 2), surface water salinity was apparently lower than at the other sites, as indicated by the low $\delta^{18} \mathrm{O}$ values, probably as a result of the proximity of the ice margin and the EGC.

\subsection{Younger Dryas (YD)}

Only core PS1878 contains a clear light $\delta^{18} \mathrm{O}$ excursion $(12.8-11.9 \mathrm{ka})$ that, according to our age model, fits into the time span of the YD (12.9-11.7 ka, cf. Broecker et al., 2010). However, less prominent oxygen isotope peaks of the same age can be found in cores PS1906 and PS1910, as well as in PS1230 and PS1243 (Bauch et al., 2001). We associate these peaks also with the YD and used them for the correlation of the cores (Figs. 2, 5). The oxygen isotope record of core PS1894 contains no indications that could be linked to the YD cooling. However, as already mentioned above, this record exhibits generally low $\delta^{18} \mathrm{O}$ values $(<3.5 \%$ o across the YD interval), often lower than those of the light $\delta^{18} \mathrm{O}$ excursions in the other records. It indicates that this site was under a constant influence of relatively fresh PW, which makes the identification of a YD freshwater signal difficult. 
In general, the origin and cause of the YD has been a matter of debate for decades now (e.g., Broecker et al., 1989; Teller et al., 2005; Murton et al., 2010; Fahl and Stein, 2012; Fisher and Lowell, 2012; Not and Hillaire-Marcel, 2012). A discharge of large amounts of freshwater from the deglacial Lake Agassiz to the North Atlantic and, in particular, to the areas of deep water convection is still considered the most likely cause for the YD (Broecker et al., 2010). While a rerouting from the Gulf of Mexico to the St. Lawrence River was proposed earlier as one triggering mechanism (Broecker et al., 1989), recent modeling results of Condron and Winsor (2012) indicate that only a freshwater discharge to the Arctic (probably via the Mackenzie Valley; cf. Tarasov and Peltier, 2006) was able to reach the deep water formation regions in the North Atlantic (including our study area) and weaken the AMOC sufficiently to trigger the YD. Our finding of a coeval low $\delta^{18} \mathrm{O}$ signal at $\sim 13 \mathrm{ka}$ in Fram Strait and Greenland Sea records is in support of hypotheses that suggest the Arctic region (including the East Greenland margin) as the main source area for the freshwater pulse. It seems unlikely that a large-volume freshwater transport occurred from the south, i.e., opposite to the dominant flow direction in the Greenland Sea. Following the modeling results of Condron and Winsor (2012), our data make the hypothesis of an Arctic trigger for the YD cold event more convincing.

\subsection{Holocene}

Although the onset of the Holocene in our records is expressed by the typical proxy changes for a glacialinterglacial transition, it looks different at the individual sites. In the southern Fram Strait (site PS1906) both the foraminiferal abundance and the percentage of subpolar species increased relatively rapidly around $12 \mathrm{ka}$. This was possibly related to the onset of enhanced surface flow of the NAC branch along the eastern Nordic Seas following shortly upon the YD (e.g., Sarnthein et al., 2003; Hald et al., 2007; Risebrobakken et al., 2011). Farther south, at sites PS1910 and PS1878, that increase was much more gradual and highest values there were reached between 10 and $8 \mathrm{ka}$. Subsurface waters at site PS1878 also warmed more slowly reaching $\sim 3{ }^{\circ} \mathrm{C}$ only around $8 \mathrm{ka}$ (Fig. 7). This confirms that in the earliest Holocene the influence of the melting Greenland Ice Sheet was strong and acted as a negative feedback to the orbitally forced climatic optimum (cf. Blaschek and Renssen, 2013). The decrease of IRD deposition at three of our sites (PS1906, PS1910, PS1878) indicates that only few icebergs still reached the southeastern Greenland Sea due to a northwestward expansion of the warmer water masses. The decrease in IRD deposition was less prominent in the southern Fram Strait at this time, most probably due to the proximity of the Transpolar Drift which still brought numerous icebergs from the Arctic Ocean into this region. Site PS1894 showed the least significant changes at the onset of the Holocene (Figs. 8, 9). The proxy data indicate that the eastern part of

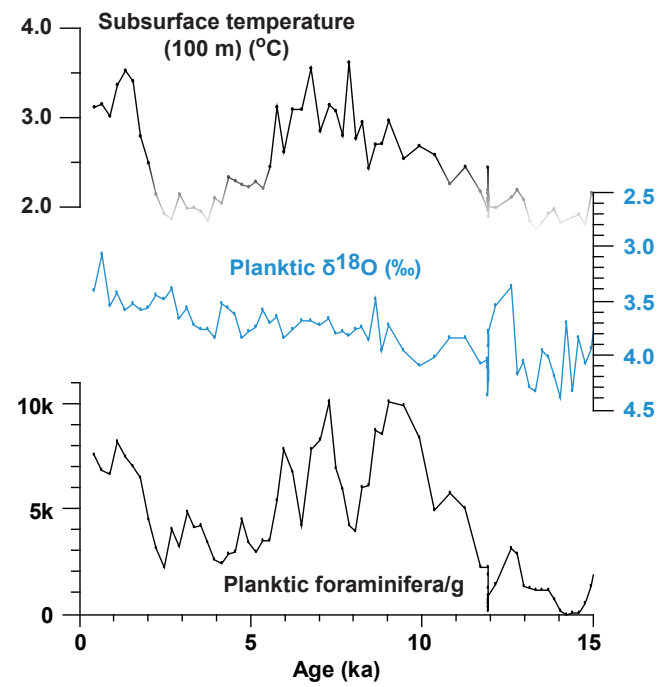

Fig. 7. Absolute subsurface temperatures calculated using the transfer function of Husum and Hald (2012) on planktic foraminifera from core PS1878 and planktic oxygen isotope and total planktic foraminiferal abundance records. Calculated temperatures below $2{ }^{\circ} \mathrm{C}$ should be considered uncertain.

the Greenland Sea remained under polar conditions with cold surface water, numerous icebergs and sea-ice cover for most of the time.

For the entire study area it is difficult to determine a coeval thermal maximum, which we define as the interval with the highest percentage of subpolar species (or highest absolute temperatures in core PS1878). Not only the course of the initial warming but also the duration and termination of the warmest interval differed between the individual sites. In the southern Fram Strait (site PS1906) the thermal maximum interval apparently started already around $11.5 \mathrm{ka}$ and ended gradually between 7 and $3 \mathrm{ka}$. At sites PS1894, PS1910 and PS1878 it was significantly shorter and can be dated to ca. 11-9.5, 10.5-7 and 8-5.5 ka, respectively. This might at least in part be attributed to uncertainties in the correlation between the records, which was mainly based on the isotope records. Nevertheless, the onset of the warmest interval around 11-9 ka accords with many other Nordic Seas records (e.g., Bauch et al., 2001; Sarnthein et al., 2003; Giraudeau et al., 2010; Risebrobakken et al., 2011; Husum and Hald, 2012) where the beginning of the Holocene thermal maximum (HTM) was related to maximum insolation in the high latitudes (e.g., Andersen et al., 2004; Risebrobakken et al., 2011) and the maximum in northward oceanic heat transport by the NAC (Risebrobakken et al., 2011). The late onset of the thermal maximum at site PS1878 might have resulted from the large distance between the site and the core of the NAC (Fig. 1). Since this onset was time-transgressive along the main pathway of the NAC (Hald et al., 2007), a similar development may also be expected westward. In principle, the presence of freshwater in the earliest Holocene (Fig. 5) 

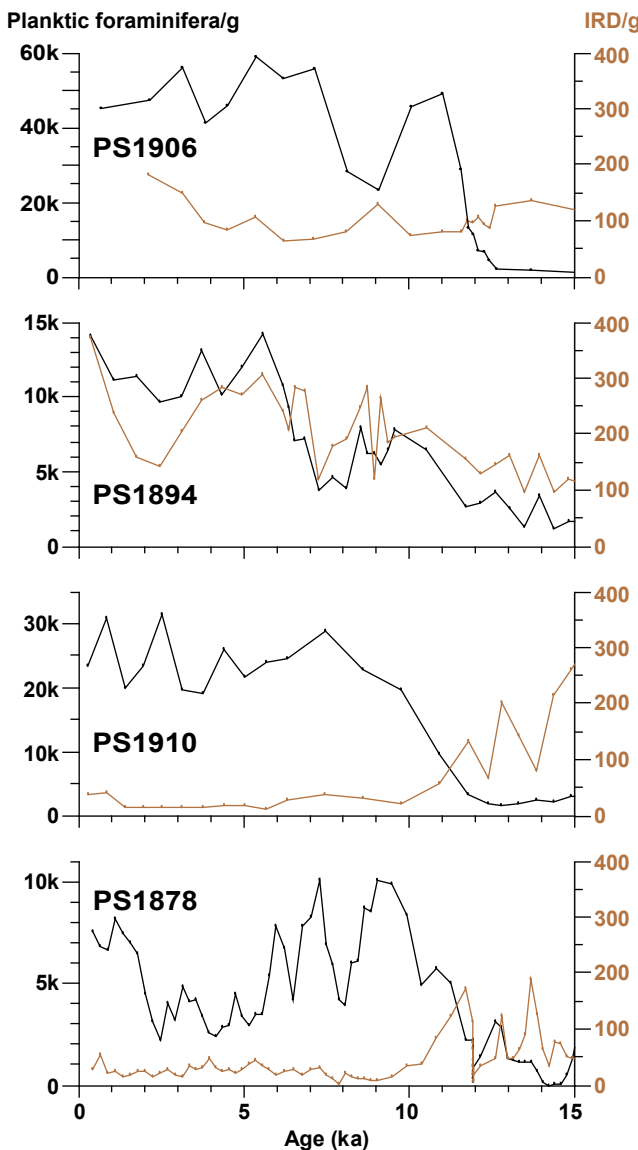

Fig. 8. Planktic foraminifera and IRD abundance (per $1 \mathrm{~g}$ dry sediment) of cores used in this study, plotted vs. age (since $15 \mathrm{ka}$ ).

may have had a cooling effect, but this should have also been the case at the other three sites. Furthermore, the relative proximity of the remnant Greenland Ice Sheet, still delivering cold meltwater, could have acted as a negative feedback for the early Holocene warming (Blaschek and Renssen, 2013). The transfer function yielded temperatures of $3-3.5^{\circ} \mathrm{C}$ at $100 \mathrm{~m}$ water depth between 8 and $5.5 \mathrm{ka}$. This is significantly warmer than modern temperatures at this depth in the Vesterisbanken area $\left(\max .2{ }^{\circ} \mathrm{C}\right.$, Thiede and Hempel, 1991) and indicates that the advection of Atlantic waters to the area between 8 (or even 10.5) and $5.5 \mathrm{ka}$ was stronger than at present.

The transition between the thermal maximum and the Neoglacial cooling as found in our records between ca. 65 and $3 \mathrm{ka}$ was also not simultaneous and, with the exception of PS1878, was much more gradual than the early Holocene warming (Figs. 7, 9). Although in cores PS1906 and PS1878 relatively late, such a timing is in good general agreement with other studies (e.g., Bauch et al., 2001; Sarnthein et al., 2003; Hald et al., 2007; Giraudeau et al., 2010; Rasmussen and Thomsen, 2010; Husum and Hald, 2012; Werner et al., 2013; for some remarkable exceptions see Risebrobakken et

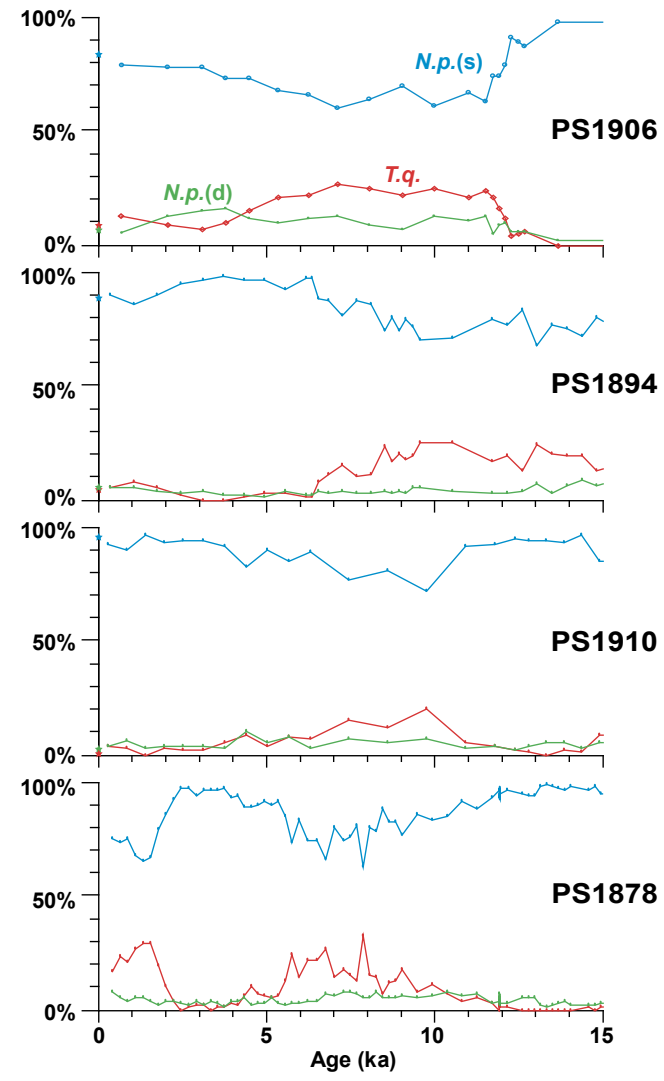

Fig. 9. Relative abundance of the three most common planktic foraminifera species in cores used in this study, plotted vs. age (since $15 \mathrm{ka}$ ). Abbreviations as in Fig. 4. Asterisks mark the modern (core-top) values (own data)

al., 2011). The Neoglacial cooling was very likely forced primarily by decreasing insolation (Andersen et al., 2004), while the regional variations in its timing and scale are a manifestation of the reorganization of the specific water mass configuration in the Nordic Seas. This reorganization involved, e.g., changes in the strength and routing of the individual NAC and EGC branches, the amount of meltwater, and the relocation of the convection centers and eventually resulted in the establishment of a type of overall water mass distribution and circulation as we see it today (Bauch et al., 2001).

The $\delta^{13} \mathrm{C}$ "plateau" between ca. 7 and $3 \mathrm{ka}$ (Fig. 5) is common in Nordic Seas records (e.g., Vogelsang, 1990; Fronval and Jansen, 1997; Bauch et al., 2001; Sarnthein et al., 2003; Risebrobakken et al., 2011; Werner et al., 2013) and reflects a period of maximum ventilation of subsurface waters, relatively stable and modern-like environmental conditions (Bauch et al., 2001; Sarnthein et al., 2003), and perhaps a significantly changed surface water structure (Bauch and Weinelt, 1997). Its onset also corresponds to the establishment of the modern Iceland-Scotland Overflow Water (Thornalley et al., 2010) and AMOC strengthening (Hall 
et al., 2004). Our benthic $\delta^{13} \mathrm{C}$ records (Fig. 6) and other benthic records from the Nordic Seas (Bauch et al., 2001; Sarnthein et al., 2003) also exhibit relatively high values in this interval. This implies good ventilation of the bottom water and suggests that intensive deep water convection took place in the Nordic Seas between 7 and $3 \mathrm{ka}$. An AMOC intensification after $7 \mathrm{ka}$ would also imply enhanced inflow of AW and PW into the Greenland Sea since the increased convection rate must be compensated by an increased inflow of both saline AW from the south and cold PW from the north. The increasing influence of cold PW amplified the Neoglacial cooling in the area, which might explain the relatively rapid warm-cold transition at site PS1878 at $5.5 \mathrm{ka}$, similar to what was found in the eastern Fram Strait (Werner et al., 2013). The cooling, in turn, likely enhanced sea-ice formation and strong winds, which opened up ice leads and provoked super-cooling processes further intensifying deep water formation. The bottom water at site PS1878 was particularly well ventilated compared to other Holocene records from the Nordic Seas (Fig. 6, cf. Bauch et al., 2001; Sarnthein et al., 2003). This indicates that deep convection was taking place in the central Greenland Sea, in the proximity of this site, with maximum vigor between 7 and $3 \mathrm{ka}$.

The planktic $\delta^{13} \mathrm{C}$ decrease after around $3 \mathrm{ka}$, observed in all our records (Fig. 5), appears to be a sound stratigraphic time marker in many Nordic Seas records (Bauch and Weinelt, 1997). Moreover, as it occurs all across the Nordic Seas including the Barents Sea (e.g., Vogelsang, 1990; Fronval and Jansen, 1997; Bauch et al., 2001; Sarnthein et al., 2003; Risebrobakken et al., 2011; Werner et al., 2013) this event clearly bears a supraregional implication. A reconstruction of sea-ice conditions in the Fram Strait (Müller et al., 2012) revealed increasing sea-ice coverage since $8 \mathrm{ka}$. At about $3 \mathrm{ka}$ a further significant expansion of the sea-ice cover occurred and sea-ice conditions became more fluctuating. Although in the record from the East Greenland Shelf (Müller et al., 2012) no increase in sea-ice coverage is observed before $3 \mathrm{ka}$ (perhaps because this area was strongly influenced by sea ice during the entire Holocene), the total sea-ice cover in the Nordic Seas was probably increasing. A similar timing in ice increase is also confirmed for the western Barents Sea slope (Sarnthein et al., 2003). Renssen et al. (2006) indicated that a negative solar irradiance anomaly and associated cooling may cause an expansion of sea ice and a temporary relocation of deep water formation sites in the Nordic Seas. One of the strongest anomalies in the Holocene occurred between 2.85 and $2.6 \mathrm{ka}$ and could have triggered the sudden increase in sea-ice extent, increased the stratification of the upper water layers and decreased the ventilation of the subsurface water. This solar irradiance anomaly may also have triggered the increase in ice rafting in the North Atlantic around that time (Bond et al., 2001; Renssen et al., 2006).

In two of our benthic carbon isotope records (PS1910 and PS1878, Fig. 6) we observe a decrease of values around $3 \mathrm{ka}$, which paralleled that in the planktic record. This is, however, not generally the case elsewhere (e.g., at site PS1894 or in the central and eastern Nordic Seas; Bauch et al., 2001; Sarnthein et al., 2003; Werner et al., 2013). The decrease in benthic $\delta^{13} \mathrm{C}$ values suggests that, probably as a result of a more extensive sea-ice cover and a stronger stratification of the upper water layers, deep convection diminished or did not reach down to maximum depth of the basins any longer (Renssen et al., 2006). Sites PS1910 and PS1878 were most likely located closest to the convection center and the decrease in convection rate or depth was recorded here as a benthic $\delta^{13} \mathrm{C}$ decrease. At other sites that were located farther from the convection center, the bottom waters were not as well ventilated before $3 \mathrm{ka}$ and therefore the relative decrease in ventilation was not large enough to be recorded in the sediment archive.

As described earlier (Telesiński et al., 2013), significant changes are observed in core PS1878 since $3 \mathrm{ka}$. The total foraminiferal abundance (Fig. 8) and percentage of subpolar species (Fig. 9) increase and planktic carbon and oxygen isotope ratios decrease. These changes were interpreted as evidence of a warming of subsurface waters caused by an NAO-induced increase in AW inflow, amplified by stronger upper water layers stratification (Telesiński et al., 2013). The benthic data from core PS1878 show that the planktic and the two benthic oxygen isotope records, which in the older part of the record ran roughly parallel to each other, diverge after $3 \mathrm{ka}$ (Figs. 5, 6). The planktic values begin to decrease after the stable interval of the Middle Holocene and $O$. umbonatus values start to increase, while $C$. wuellerstorfi oxygen isotope ratios follow the earlier slightly decreasing trend. As a result of the decrease in convection rate and depth, probably not only the surface and bottom waters began to differentiate from each other, but also, at a smaller scale, the epibenthic and infaunal biotopes became more distinct than before due to more stagnant conditions.

In the other records from the Greenland Sea the changes after $3 \mathrm{ka}$ are not as obvious. At site PS1894, strongly affected by PW, the conditions seem to be similar to those at other sites during the LGM, with at least seasonally open water conditions and somewhat warmer upper water layers (Figs. 5, 8, 9; see discussion above). Virtually no indications of warming or increased AW influence can be found at sites PS1906 and PS1910 at that time.

The high-resolution subsurface temperature reconstruction from site PS1878 indicates a warming from ca. $2{ }^{\circ} \mathrm{C}$ at $2.5 \mathrm{ka}$ to $3.5^{\circ} \mathrm{C}$ at $1.5 \mathrm{ka}$, confirming that conditions in the central Greenland Sea in the late Holocene were comparable to the early Holocene warm interval (cf. Telesiński et al., 2013). The scale of this warming $\left(1.5^{\circ} \mathrm{C}\right)$ is comparable to that of the modern warming in the Arctic (e.g., Spielhagen et al., 2011) though, of course, on a significantly longer timescale. A comparison with the faunal data from other Greenland Sea cores (Fig. 9) shows that this phenomenon was confined to the central part of the Greenland Sea and may have resulted from the co-occurrence of the stronger 
water column stratification and the enhanced inflow of Atlantic waters to the site.

\section{Summary and conclusions}

With the records presented in this study we were able here to reconstruct for the first time a millennial- to multicentennialscale image of the late glacial and Holocene paleoceanographic evolution in the northern and central Greenland Sea. Despite the low sedimentation rates in the northern part of the study area and the related chronological uncertainties, the correlation and comparison with a high resolution record PS1878 (Telesiński et al., 2013) allowed us to study the spatial and temporal variability of the most important oceanographic processes. The integration of surface, subsurface and bottom water proxies gave an almost complete image.

During the LGM environmental conditions were to a large extent similar across the Greenland Sea. Cold conditions with a dense sea-ice cover, numerous icebergs and low biological productivity prevailed in the area. During the deglaciation the Greenland Sea was affected by freshwater discharges. Although we argue that they were roughly simultaneous (between 18 and $15 \mathrm{ka}$ ) and may have had a common trigger mechanism, their sources and character were probably different. During the YD the Greenland Sea was affected by a major deglacial freshwater discharge most probably originating from the Arctic. Our data suggest a thicker but weaker halocline and a deepening of AW.

The onset, duration and decline of the early Holocene warm interval were apparently different in age and scale at each site, reflecting regional differences in the reorganization of the ocean circulation of the area. As peak warming occurred not simultaneously at all sites, the thermal maximum in the central Greenland Sea was not reached until ca. $8 \mathrm{ka}$, which is relatively late compared to other Nordic Seas records. Maximum subsurface temperatures $\left(>3^{\circ} \mathrm{C}\right)$ were higher than at present, indicating a strong influence of Atlantic waters. Since $7 \mathrm{ka}$ high $\delta^{13} \mathrm{C}$ values, both planktic and benthic, indicate the establishment of the modern ocean circulation system in the Nordic Seas with maximum deep convection in the Greenland Sea. Despite a strong AMOC, decreasing insolation led to the Neoglacial cooling and an increase in sea-ice coverage. At 3-2.8 ka a solar irradiance minimum may have triggered a rapid expansion of the sea-ice cover that led to a stronger stratification of the upper water layers and, subsequently, to a weakening of deep convection in the Greenland Sea and of the AMOC. Eventually, an increase in AW inflow into the Nordic Seas led to subsurface warming in the central Greenland Sea (site PS1878). Probably due to a relatively stable water stratification, as well as increased presence of sea ice (and thus an isolation of the subsurface water from the atmosphere and other water masses), subsurface temperatures rose again to a level comparable with the early Holocene thermal maximum at this site.
Comparison of the Greenland Sea records suggests insolation to be the primary driver controlling the regional paleoceanographic evolution while the routing and intensity of AW inflow seems to control the spatial variability in the area. Other processes - such as sea-ice formation, deep convection, freshwater discharges, etc. - also played an important role in the observed local differences.

Acknowledgements. This work is a contribution to the CASE Initial Training Network funded by the European Community's 7th Framework Programme FP7 2007/2013, Marie Curie Actions, under Grant Agreement no. 238111. We thank reviewers Juliane Müller and Thomas Cronin, as well as Christelle Not and Kirstin Werner for their constructive criticism and suggestions which improved the manuscript. Our gratitude goes to Katrine Husum for her help with performing the transfer function calculations. We are grateful to Lulzim Haxhiaj as well as Helmut Erlenkeuser and his staff for performing the stable isotope measurements and to the Leibniz Laboratory, Kiel University, and the Poznan Radiocarbon Laboratory for the AMS ${ }^{14} \mathrm{C}$ datings.

The service charges for this open access publication have been covered by a Research Centre of the Helmholtz Association.

Edited by: H. Renssen

\section{References}

Andersen, C., Koç, N., Jennings, A. E., and Andrews, J. T.: Nonuniform response of the major surface currents in the Nordic Seas to insolation forcing: Implications for the Holocene climate variability, Paleoceanography, 19, PA2003, doi:10.1029/2002PA000873, 2004.

Bauch, D. and Bauch, H. A.: Last glacial benthic foraminiferal $\delta^{18} \mathrm{O}$ anomalies in the polar North Atlantic: A modern analogue evaluation, J. Geophys. Res., 106, 9135-9143, 2001.

Bauch, H. A. and Erlenkeuser, H.: Interpreting Glacial-Interglacial Changes in Ice Volume and Climate From Subarctic Deep Water Foraminiferal $\delta^{18} \mathrm{O}$, in: Earth's Climate and Orbital Eccentricity: The Marine Isotope Stage 11 Question, Geoph. Monog. Series 137, edited by: Droxler, L. H., Poore, A. W., and Burckle, R. Z., American Geophysical Union, Washington, D.C., 87-102, 2003.

Bauch, H. A. and Weinelt, M. S.: Surface water changes in the Norwegian Sea during last deglacial and Holocene times, Quaternary Sci. Rev., 16, 1115-1124, 1997.

Bauch, H. A., Erlenkeuser, H., Spielhagen, R. F., Struck, U., Matthiessen, J., Thiede, J., and Heinemeier, J.: A multiproxy reconstruction of the evolution of deep and surface waters in the subarctic Nordic seas over the last 30,000 yr, Quaternary Sci. Rev., 20, 659-678, 2001.

Blaschek, M. and Renssen, H.: The Holocene thermal maximum in the Nordic Seas: the impact of Greenland Ice Sheet melt and other forcings in a coupled atmosphere-sea-ice-ocean model, Clim. Past, 9, 1629-1643, doi:10.5194/cp-9-1629-2013, 2013. 
Bond, G. C., Kromer, B., Beer, J., Muscheler, R., Evans, M. N., Showers, W., Hoffmann, S., Lotti-Bond, R., Hajdas, I., and Bonani, G.: Persistent solar influence on North Atlantic climate during the Holocene, Science, 294, 2130-2136, doi:10.1126/science.1065680, 2001.

Broecker, W. S., Kennett, J. P., Flower, B. P., Teller, J. T., Trumbore, S., Bonani, G., and Wolfli, W.: Routing of meltwater from the Laurentide Ice Sheet during the Younger Dryas cold episode, Nature, 341, 318-321, 1989.

Broecker, W. S., Denton, G. H., Edwards, R. L., Cheng, H., Alley, R. B., and Putnam, A. E.: Putting the Younger Dryas cold event into context, Quaternary Sci. Rev., 29, 1078-1081, doi:10.1016/j.quascirev.2010.02.019, 2010.

Carstens, J., Hebbeln, D., and Wefer, G.: Distribution of planktic foraminifera at the ice margin in the Arctic (Fram Strait), Mar. Micropaleontol., 29, 257-269, 1997.

Clark, D. L. and Hanson, A.: Central Arctic Ocean sediment texture: A key to ice transport mechanism, in: Glacial-marine sedimentation, edited by: Molnia, B. F., Plenum Press, New York, 301-330, 1983.

Clark, P. U. and Mix, A. C.: Ice sheets and sea level of the Last Glacial Maximum, Quaternary Sci. Rev., 21, 1-7, doi:10.1016/S0277-3791(01)00118-4, 2002.

Condron, A. and Winsor, P.: Meltwater routing and the Younger Dryas, P. Natl. Acad. Sci. USA, 109, 19928-19933, doi:10.1073/pnas.1207381109, 2012.

Dokken, T. M. and Jansen, E.: Rapid changes in the mechanism of ocean convection during the last glacial period, Nature, 401, 458-461, 1999.

Duplessy, J. C., Labeyrie, L. D., and Blanc, P. L.: Norwegian Sea Deep Water Variations over the Last Climatic Cycle: PaleoOceanographical Implications, in: Long and Short Term Variability of Climate, edited by: Wanner, H. and Siegenthaler, U. Springer, New York, 83-116, 1988.

Fahl, K. and Stein, R.: Modern seasonal variability and deglacial/Holocene change of central Arctic Ocean sea-ice cover: New insights from biomarker proxy records, Earth Planet. Sc. Lett., 351-352, 123-133, doi:10.1016/j.epsl.2012.07.009, 2012.

Fisher, T. G. and Lowell, T. V.: Testing northwest drainage from Lake Agassiz using extant ice margin and strandline data, Quatern. Int., 260, 106-114, doi:10.1016/j.quaint.2011.09.018, 2012.

Fronval, T. and Jansen, E.: Eemian and early Weichselian (140$60 \mathrm{ka})$ paleoceanography and paleoclimate in the Nordic seas with comparisons to Holocene conditions, Paleoceanography, 12, 443-462, 1997.

Giraudeau, J., Grelaud, M., Solignac, S., Andrews, J. T., Moros, M., and Jansen, E.: Millennial-scale variability in Atlantic water advection to the Nordic Seas derived from Holocene coccolith concentration records, Quaternary Sci. Rev., 29, 1276-1287, doi:10.1016/j.quascirev.2010.02.014, 2010.

Hald, M., Andersson, C., Ebbesen, H., Jansen, E., KlitgaardKristensen, D., Risebrobakken, B., Salomonsen, G. R., Sarnthein, M., Sejrup, H. P., and Telford, R. J.: Variations in temperature and extent of Atlantic Water in the northern North Atlantic during the Holocene, Quaternary Sci. Rev., 26, 3423-3440, doi:10.1016/j.quascirev.2007.10.005, 2007.
Hall, I. R., Bianchi, G. G., and Evans, J. R.: Centennial to millennial scale Holocene climate-deep water linkage in the North Atlantic, Quaternary Sci. Rev., 23, 1529-1536, doi:10.1016/j.quascirev.2004.04.004, 2004.

Hansen, B. and Østerhus, S.: North Atlantic-Nordic Seas exchanges, Prog. Oceanogr., 45, 109-208, doi:10.1016/S00796611(99)00052-X, 2000.

Hanslik, D., Jakobsson, M., Backman, J., Björck, S., Sellén, E., O'Regan, M., Fornaciari, E., and Skog, G.: Quaternary Arctic Ocean sea ice variations and radiocarbon reservoir age corrections, Quaternary Sci. Rev., 29, 3430-3441, doi:10.1016/j.quascirev.2010.06.011, 2010.

Hillaire-Marcel, C. and de Vernal, A.: Stable isotope clue to episodic sea ice formation in the glacial North Atlantic, Earth Planet. Sc. Lett., 268, 143-150, doi:10.1016/j.epsl.2008.01.012, 2008.

Husum, K. and Hald, M.: Arctic planktic foraminiferal assemblages: Implications for subsurface temperature reconstructions, Mar. Micropaleontol., 96-97, 38-47, doi:10.1016/j.marmicro.2012.07.001, 2012.

Juggins, S.: C2, Version 1.7.2, Software for Ecological and Palaeoecological Data Analysis and Visualization, http://www.campus. ncl.ac.uk/staff/Stephen.Juggins/index.html, University of Newcastle, Newcastle upon Tyne, UK, 2011.

Marshall, J. and Schott, F.: Open-ocean convection: Observations, theory, and models, Rev. Geophys., 37, 1-64, 1999.

McManus, J. F., Francois, R., Gherardi, J.-M., Keigwin, L. D., and Brown-Leger, S.: Collapse and rapid resumption of Atlantic meridional circulation linked to deglacial climate changes, Nature, 428, 834-837, doi:10.1038/nature02494, 2004.

Müller, J., Werner, K., Stein, R., Fahl, K., Moros, M., and Jansen, E.: Holocene cooling culminates in sea ice oscillations in Fram Strait, Quaternary Sci. Rev., 47, 1-14, doi:10.1016/j.quascirev.2012.04.024, 2012.

Murton, J. B., Bateman, M. D., Dallimore, S. R., Teller, J. T., and Yang, Z.: Identification of Younger Dryas outburst flood path from Lake Agassiz to the Arctic Ocean, Nature, 464, 740-743, doi:10.1038/nature08954, 2010.

Nørgaard-Pedersen, N., Spielhagen, R. F., Erlenkeuser, H., Grootes, P. M., Heinemeier, J., and Knies, J.: Arctic Ocean during the Last Glacial Maximum: Atlantic and polar domains of surface water mass distribution and ice cover, Paleoceanography, 18, 1-19, doi:10.1029/2002PA000781, 2003.

Not, C. and Hillaire-Marcel, C.: Enhanced sea-ice export from the Arctic during the Younger Dryas, Nature Comm., 3, 647, doi:10.1038/ncomms1658, 2012.

Nürnberg, D., Wollenburg, I., Dethleff, D., Eicken, H., Kassens, H., Letzig, T., Reimnitz, E., and Thiede, J.: Sediments in Arctic sea ice: implications for entrainment, transport and release, Mar. Geol., 104, 185-214, 1994.

Rasmussen, T. L. and Thomsen, E.: Stable isotope signals from brines in the Barents Sea: Implications for brine formation during the last glaciation, Geology, 37, 903-906, doi:10.1130/G25543A.1, 2009.

Rasmussen, T. L. and Thomsen, E.: Holocene temperature and salinity variability of the Atlantic Water inflow to the Nordic seas, Holocene, 20, 1223-1234, doi:10.1177/0959683610371996, 2010. 
Reimer, P., Baillie, M., Bard, E., Bayliss, A., Beck, J. W., Blackwell, P. G., Bronk Ramsey, C., Buck, C. E., Burr, G. S., Edwards, R. L., Friedrich, M., Grootes, P. M., Guilderson, T. P., Hajdas, I., Heaton, T. J., Hogg, A. G., Hughen, K. A., Kaiser, K. F., Kromer, B., McCormac, F. G., Manning, S. W., Reimer, R. W., Richards, D. A., Southon, J. R., Talamo, S., Turney, C. S. M., van der Plicht, J., and Weyhenmeyer, C. E.: IntCal09 and Marine09 radiocarbon age calibration curves, 0-50,000 years cal BP, Radiocarbon, 51, 1111-1150, 2009.

Renssen, H., Goosse, H., and Muscheler, R.: Coupled climate model simulation of Holocene cooling events: oceanic feedback amplifies solar forcing, Clim. Past, 2, 79-90, doi:10.5194/cp-2-792006, 2006.

Risebrobakken, B., Dokken, T., Smedsrud, L. H., Andersson, C., Jansen, E., Moros, M., and Ivanova, E. V.: Early Holocene temperature variability in the Nordic Seas: The role of oceanic heat advection versus changes in orbital forcing, Paleoceanography, 26, PA4206, doi:10.1029/2011PA002117, 2011.

Rudels, B. and Quadfasel, D.: Convection and deep water formation in the Arctic Ocean-Greenland Sea System, J. Mar. Syst., 2, 435450, doi:10.1016/0924-7963(91)90045-V, 1991.

Rudels, B., Friedrich, H. J., and Quadfasel, D.: The Arctic Circumpolar Boundary Current, Deep Sea-Res. Pt. II, 46, 1023-1062, doi:10.1016/S0967-0645(99)00015-6, 1999.

Sarnthein, M., Jansen, E., Weinelt, M., Arnold, M., Duplessy, J. C., Erlenkeuser, H., Flatøy, A., Johannessen, G., Johannessen, T., Jung, S., Koc, N., Labeyrie, L., Maslin, M., Pflaumann, U., and Schulz, H.: Variations in Atlantic surface ocean paleoceanography, $50^{\circ}-80^{\circ} \mathrm{N}$ : A time-slice record of the last 30,000 years, $\mathrm{Pa}-$ leoceanography, 10, 1063-1094, 1995.

Sarnthein, M., van Kreveld, S., Erlenkeuser, H., Grootes, P. M., Kucera, M., Pflaumann, U., and Schulz, M.: Centennial-tomillennial-scale periodicities of Holocene climate and sediment injections off the western Barents shelf, $75^{\circ} \mathrm{N}$, Boreas, 32, 447461, doi:10.1080/03009480310003351, 2003.

Spielhagen, R. F. and Erlenkeuser, H.: Stable oxygen and carbon isotopes in planktic foraminifers from Arctic Ocean surface sediments: Reflection of the low salinity surface water layer, Mar. Geol., 119, 227-250, doi:10.1016/0025-3227(94)90183-X, 1994.

Spielhagen, R. F., Baumann, K.-H., Erlenkeuser, H., Nowaczyk, N. R., Nørgaard-Pedersen, N., Vogt, C., and Weiel, D.: Arctic Ocean deep-sea record of northern Eurasian ice sheet history, Quaternary Sci. Rev., 23, 1455-1483, doi:10.1016/j.quascirev.2003.12.015, 2004.

Spielhagen, R. F., Werner, K., Aagaard-Sørensen, S., Zamelczyk, K., Kandiano, E., Budeus, G., Husum, K., Marchitto, T. M., and Hald, M.: Enhanced Modern Heat Transfer to the Arctic by Warm Atlantic Water, Science, 331, 450-453, doi:10.1126/science.1197397, 2011.
Stanford, J. D., Rohling, E. J., Bacon, S., Roberts, A. P., Grousset, F. E., and Bolshaw, M.: A new concept for the paleoceanographic evolution of Heinrich event 1 in the North Atlantic. Quaternary Sci. Rev., 30, 1047-1066, doi:10.1016/j.quascirev.2011.02.003, 2011.

Stern, J. V. and Lisiecki, L. E.: North Atlantic circulation and reservoir age changes over the past 41,000 years, Geophys. Res. Lett., 40, 3693-3697, doi:10.1002/grl.50679, 2013.

Stuiver, M. and Reimer, P. J.: Radiocarbon calibration program, Radiocarbon, 35, 215-230, 1993.

Swift, J.: The Arctic Waters, in: The Nordic Seas, edited by: Hurdle, B., Springer, New York, 129-151, 1986.

Tarasov, L. and Peltier, W. R.: A calibrated deglacial drainage chronology for the North American continent: evidence of an Arctic trigger for the Younger Dryas, Quaternary Sci. Rev., 25, 659-688, doi:10.1016/j.quascirev.2005.12.006, 2006.

Telesiński, M. M., Spielhagen, R. F., and Lind, E. M.: A highresolution Late Glacial and Holocene paleoceanographic record from the Greenland Sea, Boreas, doi:10.1111/bor.12045, in press, 2013.

Teller, J. T., Boyd, M., Yang, Z., Kor, P. S. G., and Mokhtari Fard, A.: Alternative routing of Lake Agassiz overflow during the Younger Dryas: new dates, paleotopography, and a re-evaluation, Quaternary Sci. Rev., 24, 1890-1905, doi:10.1016/j.quascirev.2005.01.008, 2005.

Thiede, J. and Hempel, G.: The Expedition ARKTIS-VII/1 of RV "POLARSTERN" in 1990, Ber. Polarforsch., 80, 137 pp., 1991.

Thornalley, D. J. R., Elderfield, H., and McCave, I. N.: Intermediate and deep water paleoceanography of the northern North Atlantic over the past 21,000 years, Paleoceanography, 25, 1-17, doi:10.1029/2009PA001833, 2010

Vogelsang, E.: Paläo-Ozeanographie des Europäischen Nordmeeres an Hand stabiler Kohlenstoff- und Sauerstoffisotope - Paleoceanography of the Nordic seas on the basis of stable carbon and oxygen isotopes, Berichte aus dem Sonderforschungsbereich 313, Nr. 23, Univ. Kiel, Kiel, 1990.

Waelbroeck, C., Duplessy, J. C., Michel, E., Labeyrie, L., Paillard, D., and Duprat, J.: The timing of the last deglaciation in North Atlantic climate records, Nature, 412, 724-727, doi:10.1038/35089060, 2001.

Werner, K., Spielhagen, R. F., Bauch, D., Christian Hass, H., and Kandiano, E.: Atlantic Water advection versus sea-ice advances in the eastern Fram Strait during the last 9 ka: Multiproxy evidence for a two-phase Holocene, Paleoceanography, 28, 283295, doi:10.1002/palo.20028, 2013. 